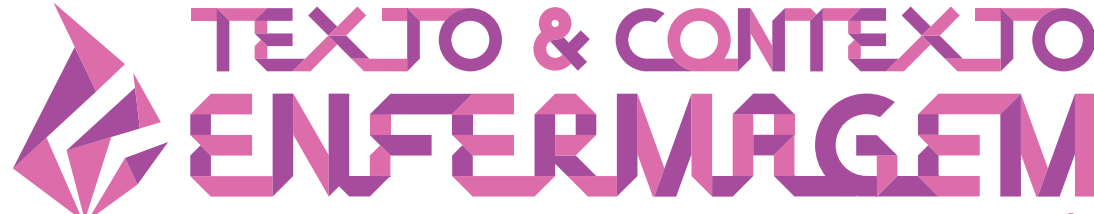

TEXT \& CONTEXT NURSING TEXTO \& CONTEXTO ENFERMERÍA

\section{EMPOWERMENT OF NURSES FROM A HOSPITAL IN THE SOUTH OF CHILE}

\author{
Karen Andrea Antiquera Masias ${ }^{1}$ (c) \\ José Luís Guedes dos Santos ${ }^{2}$ (iD \\ Alacoque Lorenzini Erdmann²
}

Hospital Clínico de Magallanes. Punta Arenas, Chile. ${ }^{2}$ Universidade Federal de Santa Catarina, Programa de Pós-graduação em Enfermagem. Florianópolis, Santa Catarina, Brasil.

\begin{abstract}
Objective: to identify the level of empowerment among the nurses from a hospital located in the south of Chile and verify its potential association with personal and professional characterization variables.

Method: cross-sectional and descriptive study conducted with 117 nurses from a hospital in the south of Chile. Data were collected in 2018 using a personal and professional characterization form and the Spanish version of the Conditions of Work Effectiveness Questionnaire II. Data were analyzed using descriptive and inferential statistics.

Results: the means of the factors of the empowerment scale were: Opportunity (4.11 \pm 0.82$)$; Information (3.81 \pm 0.90$)$; Support (3.81 \pm 0.86$)$, and Resources (3.13 \pm 0.97$)$. Statistically significant differences were found between empowerment and having greater professional experience, working in the medical-surgical unit, having from 3 to 10 patients under responsibility, job satisfaction, and intention to quit their jobs.

Conclusion: the nurses reported a positive perception of empowerment in their roles, especially concerning having opportunities to perform tasks that contribute to acquiring new knowledge and skills at work.
\end{abstract}

DESCRIPTORS: Nursing. Working environment. Nursing, supervisory. Nursing administration research. Hospital, public. Power, psychological. 


\section{EMPODERAMIENTO DE LOS ENFERMEROS DE UN HOSPITAL DEL SUR DE CHILE}

\section{RESUMEN}

Objetivo: identificar el nivel de empoderamiento de los enfermeros de un hospital en el Sur de Chile y verificar posibles asociaciones con variables de caracterización personal y profesional.

Método: se realizó un estudio transversal y descriptivo, con un muestreo de 117 enfermeros de un Hospital del sur de Chile. La recogida de datos fue realizada en 2018, con una ficha de caracterización personal y profesional y la versión en español del Conditions of Work Effectiveness Questionnaire II. Los datos fueron analizados a través de estadísticas descriptivas e inferenciales.

Resultados: las medias de los factores de la escala de empoderamiento fueron: Oportunidad $(4,11 \pm$ $0,82)$; Información $(3,81 \pm 0,90)$; Suporte $(3,81 \pm 0,86)$ y Recursos $(3,13 \pm 0,97)$. Se identificó diferencia estadísticamente significativa del empoderamiento con más tiempo de experiencia profesional, el servicio Bloque Médico Quirúrgico, con una cantidad de 3 a 10 pacientes bajo su responsabilidad, satisfacción con el trabajo e intención de dejar el trabajo.

Conclusión: los enfermeros tienen una percepción positiva acerca del empoderamiento en su rol, especialmente con relación a las oportunidades de desarrollar tareas que contribuyen para la adquisición de nuevos conocimientos y habilidades en el trabajo.

DESCRIPTORES: Enfermería. Ambiente de trabajo. Supervisión de enfermería. Investigación en administración de enfermería. Hospitales públicos. Poder (Psicología).

\section{EMPODERAMENTO DE ENFERMEIROS DE UM HOSPITAL NO SUL DO CHILE}

\section{RESUMO}

Objetivo: identificar o nível de empoderamento dos enfermeiros de um hospital no sul do Chile e verificar as possíveis associações com variáveis de caracterização pessoal e profissional.

Método: estudo transversal e descriptivo com uma amostra de 117 enfermeiros de um hospital no sul do Chile. A coleta de dados foi realizada em 2018 usando um formulário de caracterização pessoal e profissional e a versão em espanhol do Conditions of Work Effectiveness Questionnaire II. Os dados foram analisados usando estatísticas descritivas e inferenciais.

Resultados: as médias dos fatores da escala de empoderamento foram: Oportunidade $(4,11 \pm 0,82)$; Informação $(3,81 \pm 0,90)$; Suporte $(3,81 \pm 0,86)$ e Recursos $(3,13 \pm 0,97)$. Diferenças statisticamente significativas foram encontradas entre empoderamento e maior experiência professional, trabalhar no Bloco Médico Cirúrgico, ter de 3 a 10 pacientes sob responsabilidade, satisfação com o trabalho e intenção de abandonar o emprego. Conclusão: os enfermeiros têm uma percepção positiva de empoderamento em seus papéis, especialmente com relação à oportunidade de realizar tarefas que contribuem para a aquisição de novos conhecimentos e habilidades no trabalho.

DESCRITORES: Enfermagem. Ambiente de trabalho. Supervisão de enfermagem. Pesquisa em administração de enfermagem. Hospitais públicos. Poder psicológico. 


\section{INTRODUCTION}

The history of nursing in Chile shows its significant advancement as discipline and profession. In 1997, the role of nurses was recognized by Law 19,536 of the Chilean Health Legislation. Later, in 2007, with the Health Reform, management of care was a requirement in the organization of health services. ${ }^{1}$

These changes represented the repositioning of Nursing as an autonomous profession in which nurses assume the responsibility for the management of care in terms of production, maintenance and recovery of people's health. ${ }^{2}$ In this sense, the management of care corresponds to the exercise of personal, professional and instrumental competencies to organize, monitor, link, and coordinate care and workflows to promote quality care delivery. ${ }^{3-4}$

Thus, nurses have the legal foundations for care practice and especially to manage it as their filed of expertise. ${ }^{2}$ Despite advancements in regulations concerning the role of nurses, they have not necessarily promoted the organization of work and the adoption of management models that strengthen the autonomous work of nurses and their empowerment to exercise care managment. ${ }^{1,5}$

Conceptualizing empowerment is not a simple task as the literature presents a wide diversity of definitions. In general, empowerment is the process by which people enhance their competencies to promote positive changes in the conditions they live in. Thus, developing and strengthening trust, competence, and vision is necessary for individuals to work as protagonists in their contexts. It also means that all individuals have access to decision-making that affects their future when they participate in privileged spaces and decision-making within the work environment. Empowerment enables increased power and autonomy in interpersonal and organizational relationships. ${ }^{6-7}$

Empowerment implies that people should have the power to carry out meaningful work, in environments that allow them to exercise personal management to achieve work goals. ${ }^{8-9}$ In the nursing field, nurses seek professional empowerment over time to obtain greater autonomy within the health staff and society, which is considered an essential component in the consolidation of nursing as a science, profession, and social practice. Thus, nurses' access to decision-making, the power to work with the staff, and control, lead to a higher level of professional empowerment. ${ }^{7}$

Empowerment derives from a structured environment that provides nurses access to opportunities, information, support, and resources. High levels of empowerment positively influence the performance of nurses, confidence in management, and job satisfaction. Therefore, managers need to be attentive to their organizational practices. The quality of technical aspects of processes and services alone is not sufficient to ensure efficient organizations; investment in personnel is also necessary. ${ }^{8-9}$

Even though the implementation of a research agenda to improve nurses' practice and the outcome of patients has been discussed in Chile, ${ }^{10}$ to the best of our knowledge, this is the first study to investigate the structural empowerment of nurses in a Chilean hospital. It is necessary to study empowerment considering the importance of nurses in the management of care and the fact that nursing is the largest profession providing care to patients in hospital settings. Therefore, the questions guiding this study are: what are the levels of structural empowerment among the nurses from a hospital located in the south of Chile? What are the potential associations between levels of structural empowerment and personal and professional characterization variables?

This study's objective was to identify the level of empowerment among the nurses of a hospital located in the south of Chile and its potential association with personal and professional characterization variables. 


\section{METHOD}

A cross-sectional and descriptive study was conducted using questionnaires. The study setting was a hospital located south of Chile, with 325 beds for adult and pediatric patients.

A total of 164 nurses working in the hospital were invited, and a convenience sample of 117 participants was obtained $(71.34 \%$ of response rate). Inclusion criteria were: having at least three months' experience working in the current workplace. A period of three months was established based on the assumption that this is the minimum period workers require to establish themselves in a new workplace. No participants were excluded based on professional experience. Three participants were excluded for not having completed the questionnaires.

Data were collected using self-report instruments:

(1) Personal, professional and workplace characterization form addressing age, gender, marital status, professional experience, time of experience working in the facility, employment relationship, profession, service, number of patients under one's responsibility, another job, total workload, job satisfaction, assessment of patient care, and intention to quit the job.

Regarding employment relationship, the following classification was used: fixed-term contract (may renew annually), permanent employee, permanent substitute (vacancy pending waiting to be selected), and substitute or replacement (fixed-term job covering vacations or sick leaves). Professions included: 4-day shift clinical nurse (rotating shift schedule), daytime clinical nurse (business hours from $8 \mathrm{am}$ to $5 \mathrm{pm}$, from Monday to Friday), nursing specialties (nurses who work in chemotherapy, hemodynamics, dialysis, etc.), and Nursing supervisor/coordinator (either supervisor or head of a service or ward).

Job satisfaction and assessment of the care provided to patients were assessed using a fourpoint Likert scale. The higher the score, the greater the nurses' level of job satisfaction, and their perception of the nursing care provided to patients. Intention to quit the job was assessed using an analogical visual scale with two ends: no intention (zero) and firm intention (ten) to leave the job next year.

(2) Spanish version of the Conditions of Work Effectiveness Questionnaire II (CWEQ-II) ${ }^{9,11}$ : it measures the components of empowerment in an organizational context. Items are rated on a Likert scale ranging from 1 (none) to 5 (a lot). The questionnaire contains 12 items divided into the components of structural empowerment: (1) opportunity: the work is challenging, and there is opportunity to learn and grow; (2) information: data, knowledge and experience, awareness of the organization's goals; (3) support: feedback and guidance provided by superiors, peers, and subordinates; and (4) resources: time, supplies, and equipment needed to achieve the organization's goals.

The higher the score, the greater one's perception of empowerment.9,11 The CWEQ-II reliability was assessed using Cronbach's alpha, which showed satisfactory internal consistency in all the subscales. Alpha equal to 0.73 was found for Opportunity, 0.19 for information, 0.8 for Support, and 0.77 for Resources. Cronbach's alphas between 0.60 and 0.70 are at the lower limit of acceptability. ${ }^{12}$

Data were collected between November and December 2018. A link was sent to all the nurses via e-mail, and the questionnaires were later provided per clinical service, the supervisor of each service became responsible for collecting them anonymously in an envelope. Data collection began after approval was obtained from the Institution Review Board at the Universidad de Magallanes on July $9^{\text {th }}, 2018$. 
All the participants received clarification regarding the study's objectives and methodology and their right to access data. The participants were asked to provide free and informed consent online to participate in the study and were ensured their identities would remain confidential.

Data were then tabulated in Excel $\circledast 2013$ and analyzed using Statistical Package for the Social Sciences (SPSS) for Windows, version 19.0. Descriptive statistics were used to describe the sample using absolute and relative frequency tables for the categorical variables (gender, marital status, profession, service, another job, job satisfaction, assessment of the care provided to patients). Location and dispersion measures (mean, median, standard deviation, and minimum and maximum values) were calculated for the continuous variables (age, professional experience, time working in the facility, number of patients under one's responsibility, and intention to leave the job). The ShapiroWilk normality test was conducted for the qualitative variables.

To compare the domain means between the categories of the variables under study, the independent samples t-test or analysis of variance (ANOVA) with the post-hoc Tukey test was conducted. The distributions of the domains between the categories of the asymmetric variables (age, gender, marital status, professional experience, experience working in the facility, employment relationship, profession, service, number of patients under responsibility, another job, total workload, job satisfaction, assessment of the care provided to patients, and intention to leave the job) were compared using the Mann-Whitney or Kruskal-Wallis test. The latter, when significant, was compared to the Dunn's post-hoc test. Statistical tests were considered significant when $p<0.05$.

\section{RESULTS}

Most of the sample was composed of women (87.2\%), single (59.8\%), aged 36.85 years old on average $(S D=10.3)$. The participants mainly provided clinical care in critical care units $(36.2 \%)$ and in the medical-surgical unit (35.3\%). Table 1 presents the nurses' remaining sociodemographic data and job characteristics.

Table 2 presents the assessment of the workers' perceptions concerning the outcomes at work. Most of the nurses are satisfied with their work (55.6\%), consider that the care provided to patients is very good $(55.6 \%)$, and has no intention to quit their jobs $(72.6 \%)$.

Table 3 presents the results concerning the empowerment questionnaire according to subscales and items. The Opportunity and Resources subscales obtained the highest and lowest means, respectively. The best-rated item was "Tasks that use all of your own skills and knowledge." The item "Time available to do necessary paperwork" obtained the lowest mean. 
Table 1 - Sociodemographic data and job characteristics. Punta Arenas, Chile, 2018. $(n=117)$

\begin{tabular}{|c|c|}
\hline Variable & n (\%) \\
\hline \multicolumn{2}{|l|}{ Professional experience } \\
\hline More than 20 years & $19(16.8)$ \\
\hline 10 to 20 years & $32(28.3)$ \\
\hline 5 to 10 years & $31(27.4)$ \\
\hline 3 to 5 years & $7(6.2)$ \\
\hline Up to 3 years & $24(21.2)$ \\
\hline \multicolumn{2}{|l|}{ Time working in the facility } \\
\hline More than 20 years & $13(11.5)$ \\
\hline 10 to 20 years & $26(23)$ \\
\hline 5 to 10 years & $37(32.7)$ \\
\hline 3 to 5 years & $10(8.8)$ \\
\hline Up to 3 years & $27(23.9)$ \\
\hline \multicolumn{2}{|l|}{ Employment relationship } \\
\hline Fixed-term contract & $62(53)$ \\
\hline Permanent employee & $15(12.8)$ \\
\hline Permanente substitute & $10(8.5)$ \\
\hline Substitute or replacement & $30(25.6)$ \\
\hline \multicolumn{2}{|l|}{ Profession } \\
\hline 4-day shift Clinical Nurse & $64(54.7)$ \\
\hline Daytime Clinical Nurse & $18(15.4)$ \\
\hline Nursing Specialties & $14(12)$ \\
\hline Nursing supervisor/coordinator & $21(17.9)$ \\
\hline \multicolumn{2}{|l|}{ Service } \\
\hline Medical surgical ward & $41(35.3)$ \\
\hline Ward specialties & $17(14.7)$ \\
\hline Outpatient care & $9(7.8)$ \\
\hline Critical care units & $42(36.2)$ \\
\hline Management service & $7(6)$ \\
\hline \multicolumn{2}{|c|}{ Number of patients under one's responsibility } \\
\hline 3 to 10 patients & $29(37.7)$ \\
\hline 11 to 15 patients & $10(13)$ \\
\hline 16 to 20 patients & $6(7.8)$ \\
\hline 21 to 30 patients & $28(36.4)$ \\
\hline 31 or more patients & $4(5.2)$ \\
\hline \multicolumn{2}{|l|}{ Other job } \\
\hline Yes & $19(16.2)$ \\
\hline No & $98(83.8)$ \\
\hline \multicolumn{2}{|l|}{ Total workload } \\
\hline Up to 44 hours & $54(46.6)$ \\
\hline More than 44 hours & $62(53.4)$ \\
\hline
\end{tabular}


Table 2 - Workers' perceptions concerning the results obtained at work. Punta Arenas, Chile, 2018. $(n=117)$

\begin{tabular}{lc}
\hline Variable & $\mathbf{n}(\%)$ \\
\hline Job satisfaction & \\
Very dissatisfied & $3(2.6)$ \\
Dissatisfied & $6(5.1)$ \\
Satisfied & $65(55.6)$ \\
Very satisfied & $43(36.8)$ \\
Assessment of the care provided to patients & \\
$\quad$ Very poor & - \\
Poor & $1(0.9)$ \\
Good & $51(43.6)$ \\
Very good & $65(55.6)$ \\
Intention to quit job & \\
No intention & $85(72.6)$ \\
1 - 5 & $20(17.1)$ \\
6 - 10 & $12(10.3)$ \\
\hline
\end{tabular}

Table 3 - Scores obtained in the empowerment questionnaire. Punta Arenas, Chile, 2018. $(n=117)$

\begin{tabular}{ll}
\hline & Mean (SD)* \\
\hline Opportunity & $\mathbf{4 . 1 1 ( 0 . 8 2 )}$ \\
Challenging work. & $3.93(1.03)$ \\
The chance to gain new skills and knowledge on the job. & $3.95(1.19)$ \\
Tasks that use all of your own skills and knowledge. & $4.44(0.76)$ \\
Information & $3.81(0.90)$ \\
Information regarding the organization's current state. & $3.75(0.91)$ \\
Information regarding the organization's values. & $3.85(0.98)$ \\
Information regarding the organization's goals. & $3.84(1.00)$ \\
Support & $3.81(0.86)$ \\
Specific information about things you do well. & $3.73(1.11)$ \\
Specific comments about things you could improve. & $3.78(0.98)$ \\
Helpful hints or problem-solving advice. & $3.91(0.96)$ \\
Resources & $3.13(0.97)$ \\
Time available to do the necessary paperwork. & $2.81(1.10)$ \\
Time available to accomplish job requirements. & $3.33(1.07)$ \\
Acquiring temporary help when needed. & $3.23(1.31)$ \\
\hline
\end{tabular}

*SD: standard deviation

Regarding differences in the comparison of the means of the empowerment questionnaire and the nurses' socio-professional variables, statistically significant differences were found between empowerment and having more extensive professional experience, working in the medical-surgical unit, having from 3 to 10 patients under responsibility, job satisfaction, and intention to quit the job. Table 4 presents the scores obtained in the factors of the empowerment questionnaire according to the nurses' characteristics. 


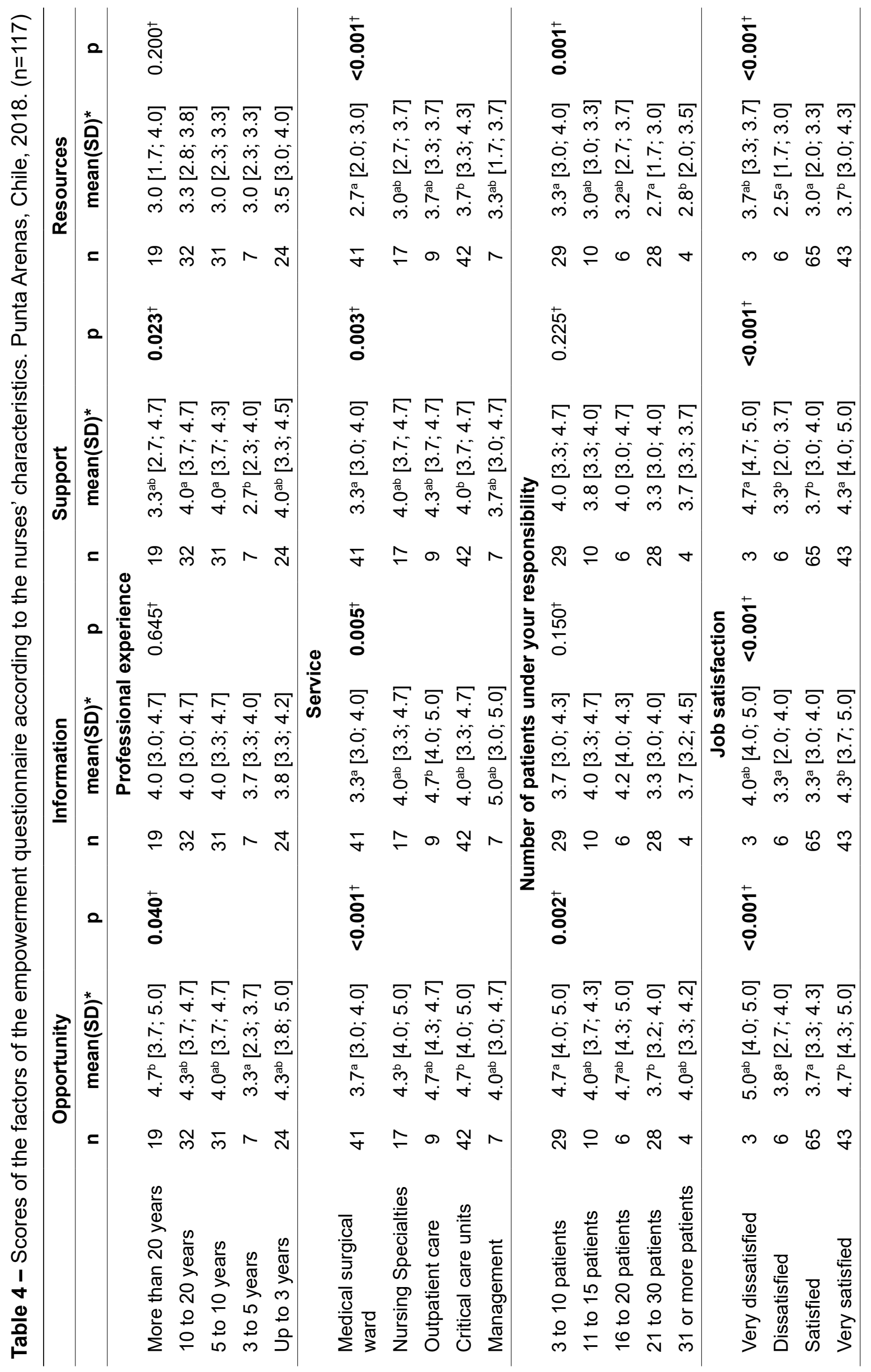




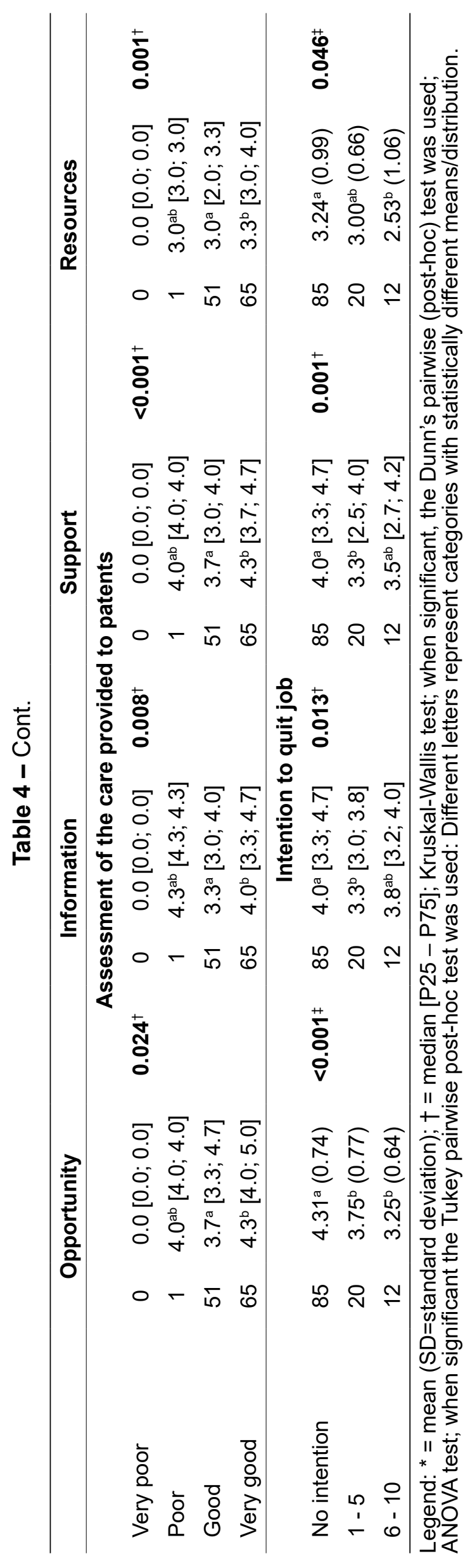




\section{DISCUSSION}

This study enabled addressing the empowerment phenomenon and its associated factors in nurses' practice in a hospital setting. Strengthening and empowering nurses are necessary conditions for the exercise of care management. Autonomous work is also essential because nurses occupy a prominent place in health institutions. First, nursing workers outnumber other professionals working in these facilities and secondly, nursing interventions enable achieving the therapeutic objectives proposed by the healthcare staff. ${ }^{7}$

In general, the results show that nurses consider their workplaces to be motivating, as most reported being satisfied with their work and had no intention to quit their jobs. According to the literature, one of the most essential factors for quality of care delivery is nurses' satisfaction with their work environment. Dissatisfied nurses tend to focus merely on fulfilling their obligations regardless of the quality of care provided, rather than focusing on patients. Dissatisfied workers also tend to leave their jobs, which increase the hospitals' financial burden, having to pay financial arrangements and training new replacement nurses. Thus, it is vital to maintain and improve working conditions to ensure nurses are satisfied and willing to keep their current job and provide improved quality of care to patients. ${ }^{13}$

Analysis of the empowerment questionnaire results showed that the Opportunity and Resources subscales obtained the highest and lowest means, respectively. Therefore, the nurses' perception of empowerment is mainly related to opportunities to develop challenging work and to learn and grow in the workplace. It explains why the best-rated item was "Tasks that use all your own skills and knowledge." Similar results concerning the empowerment questionnaire dimensions are also reported by a study that addresses nurses from three public hospitals in Portugal ${ }^{14}$ and a study that addresses nurses from an emergency service located in New Zealand. ${ }^{15}$

The lowest mean of the Resources subscale requires attention, especially regarding the time nurses have available to do the necessary paperwork. This empowerment dimension refers to the time, supplies, and equipment required for nurses to achieve the organization's goals. The environment can shape healthcare processes and improve care delivery efficiency, improving the satisfaction of both the patients and personnel. ${ }^{16}$ Lack of resources in health organizations and increased demands at work are stressors workers, especially the nursing staff, have to deal with. ${ }^{14,17}$

Regarding the scores of the empowerment questionnaire factors according to the nurses' characteristics, a statistically significant difference was found between professional experience and the Opportunity and Support dimensions. This result is explained by the fact that empowerment may be considered the construction of continuous interaction between an individual and his/her professional environment. ${ }^{18}$ Thus, it is understandable that the more experienced participants had a better perception of their empowerment level.

The number of patients under one's responsibility presented a statistically significant difference with the Opportunity and Resources factors. Having a smaller number of patients under responsibility may enable more opportunities to develop care where one has all the necessary resources and can use all his/her skills and knowledge. Hence, working conditions can contribute to improving nursing care. The literature shows that the higher the number of patients assigned to nursing workers, the higher the likelihood that results are considered harmful for patient safety. ${ }^{19}$

Regarding the hospital sectors, a statistically significant difference was found among the nurses from the medical-surgical unit in the four empowerment factors: Opportunity, Information, Support, and Resources. This unit includes all the hospital's units that provide clinical and surgical care to patients, concentrating a large number of hospitalizations and nursing personnel. ${ }^{20}$ These factors contribute to nurses' perception that they have more opportunities, information, support, and resources to perform their work. 
The statistical difference between job satisfaction and assessment of the care provided to patients and the intention to quit their job with the four domains of empowerment is in line with previous studies reporting this relationship. The more empowered a nurse is, the higher his/her level of job satisfaction ${ }^{21}$ and organizational commitment. ${ }^{22}$ Therefore, it is essential that the managers of health services provide training opportunities to employees, appropriate feedback, and problem-solving advice, promoting a greater exchange of information and communication. These are some of the strategies that may result in higher professional motivation and consequently, greater empowerment in the workplace. ${ }^{22-23}$

One of this study's limitations refers to its cross-sectional design, which is related to confounding variables that may affect the relationships between the study variables. The study design is also sensitive to certain biases, such as desirability bias or a tendency in the responses of those people who voluntarily collaborated with the study.

\section{CONCLUSION}

The nurses presented a positive perception of empowerment in their roles, especially regarding the opportunities to acquire new skills and knowledge in their work and develop tasks that use all their skills and knowledge. The Resources dimension, which refers to time, supplies, and equipment to achieve the organizational goals, obtained the lowest score among the participants.

This study's results can contribute to the formulation of policies and regulations for nurses' practice, especially concerning the management of care in hospital settings. Further studies are needed to understand the work environment's particularities and empowerment among nurses in the South-American context.

\section{REFERENCES}

1. Guerrero-Núñez $\mathrm{S}$, Cid-Henríquez P. Una reflexión sobre la autonomía y el liderazgo en enfermería. Aquichan [Internet]. 2015 [cited 2019 Oct 09];15(1):129-40. Available from: http://doi.org/10.5294/ aqui.2015.15.1.12

2. Canales-Vergara M, Valenzuela-Suazo S, Paravic-Klijn T. Condiciones de trabajo de los profesionales de enfermería en Chile. Enferm. Univ [Internet]. 2016 [cited 2019 Oct 09];13(3):17886. Available from: http://doi.org/10.1016/j.reu.2016.05.004

3. Andrade MCT, Alarcón J, Berthet A, Cantero V, Llanquipichún D, Sáez D, et al. Modelo de certificación de calidad para la gestión del cuidado en hospitales chilenos. Rev Enf Ref [Internet]. 2016 [cited 2019 Oct 09];9:65-74. Available from: http://doi.org/10.12707/riv15015

4. Ayala RA, Koch TF, Messing HB. The system of nursing in Chile: Insights from a systems theory perspective. Nurs Inq [Internet]. 2019 [cited 2019 Oct 09];26(1):e12260. Available from: https:// doi.org/10.1111/nin.12260

5. Valdebenito PJ, Barquero A, Carreño ME. Gestión del cuidado: valoración y conocimiento de enfermeros(as) de un hospital de la región metropolitana, Chile. Cienc Enferm [Internet]. 2015 [cited 2019 Oct 09];21(1):127-42. Available from: http://doi.org/10.4067/s0717-95532015000100012

6. Bernardino E, Dyniewicz AM, Carvalho KLB, Kalinowski LC, Bonat WH. Adaptação transcultural e validação do instrumento Conditions of Work Effectiveness - Questionnaire-II. Rev Latinoam Enfermagem [Internet]. 2013 [cited 2019 Oct 09];21(5):1112-8. Available from: http://www. periodicos.usp.br/rlae/article/view/76029/79674 
7. Villagra Rivera N, Ruoti Cosp M. Empoderamiento enfermero en las unidades de cuidados intensivos de adultos en el Hospital Central del Instituto de Previsión Social. Mem. Inst. Invest. Cienc Salud [Internet]. 2018 [cited 2019 Oct 09];16(1):84-93. Available from: http://revistascientificas. una.py/index.php/riic/article/download/1336/1184

8. Friend ML, Sieloff CL. Empowerment in nursing literature: an update and look to the future. Nurs Sci Q [Internet]. 2018 [cited 2019 Oct 09];31(4):355-361. Available from: https://doi. org/10.1177/0894318418792887

9. Román MJJ, Bretones FD. Spanish adaptation of the structural empowerment scale. Span J Psychol [Internet]. 2013 [cited 2019 Oct 09];16:e15. Available from: https://www.ncbi.nlm.nih. gov/pubmed/23866208

10. Simonetti M, Aiken LH, Lake ET. Nursing in Chilean Hospitals: A Research Agenda to Inform Health Policies and Improve Patient Outcomes. Hisp Health Care Int [Internet]. 2019 [cited 2020 Apr 27];17(2):79-88. Available from: https://doi.org/10.1177/1540415318819475.

11. Laschinger HKS, Finegan J, Shamian J, Wilk P. A longitudinal analysis of the impact of workplace empowerment on work satisfaction. J Organ. Behav [Internet]. 2004 [cited 2019 Oct 09];25(4):52745. Available from: https://doi.org/10.1002/job.256

12. Hair JF, Anderson RE, Tatham RL, Black WC. Análise multivariada de dados. 5th ed. Porto Alegre(BR): Bookman, 2005.

13. Suliman M, Aljezawi M. Nurses' work environment: indicators of satisfaction. J Nurs Manag [Internet]. 2018 [cited 2019 Oct 09];26(5):525-30. Available from: https://doi.org/10.1111/jonm.12577

14. Orgambídez-Ramos A, Borrego-Alés $Y$, Ruiz-Frutos $C$. Empowerment, vulnerabilidad al estrés y burnout en enfermeros portugueses. Ciênc Saúde Coletiva [Internet]. 2018 [cited 2019 Oct 09];23(1):259-66. Available from: https://doi.org/10.1590/1413-81232018231.15522015

15. Connolly M, Jacobs S, Scott K. Clinical leadership, structural empowerment and psychological empowerment of registered nurses working in an emergency department. J Nurs Manag [Internet]. 2018 [cited 2019 Oct 09];26(7):881-7. Available from: https://doi.org/10.1111/jonm.12619

16. Fay L, Carll-White A, Real K. Emergency Nurses' Perceptions of Efficiency and Design: Examining ED Structure, Process, and Outcomes. J Emerg Nurs. [Internet]. 2018 [cited 2019 Oct 09];44(3):2749. Available from: https://doi.org/10.1016/j.jen.2017.09.001

17. Padilha KG, Barbosa RL, Andolhe R, Oliveira EM, Ducci AJ, Bregalda RS, et al. Nursing workload, stress/burnout, satisfaction and incidents in a trauma intensive care units. Texto Contexto Enferm. [Internet]. 2017 [cited 2019 Oct 09];26(3):e1720016. Available from: https://doi.org/10.1590/010407072017001720016

18. Kuokkanen L, Leino-Kilpi H, Numminen O, Isoaho H, Flinkman M, Meretoja R. Newly graduated nurses' empowerment regarding professional competence and other work-related factors. BMC Nurs. [Internet]. 2016 [cited 2019 Oct 09];24(15):22. Available from: https://doi.org/10.1186/ s12912-016-0143-9

19. Magalhães AMM, Costa DG, Riboldi CO, Mergen T, Barbosa AS, Moura GMS. Association between workload of the nursing staff and patient safety outcomes. Rev Esc Enferm USP [Internet]. 2017 [cited 2019 Oct 09];51:e03255. Available from: https://doi.org/10.1590/s1980-220x2016021203255

20. Barbosa MH, Aleixo TCS, Oliveira KF, Nascimento KG, Felix MMS, Barichello E. Clima de segurança do paciente em unidades de clínica médica e cirúrgica. Rev Eletr Enf [Internet]. 2016 [cited 2019 Oct 09];18:e1183. Available from: https://doi.org/10.5216/ree.v18.39763

21. Lyden C, Sekula LK, Higgins B, Zoucha R. Job satisfaction and empowerment of self-employed nurse practitioners: a mixed methods study. J Am Assoc Nurse Pract [Internet]. 2018 [cited 2019 Oct 09];30(2):78-91. Available from: https://www.ncbi.nlm.nih.gov/pubmed/29757819 
22. Gholami M, Saki M, HosseinPour AH. Nurses' perception of empowerment and its relationship with organizational commitment and trust in teaching hospitals in Iran. J Nurs Manag [Internet]. 2019 [cited 2019 Oct 09];27:1020-29. Available from: https://doi.org/10.1111/jonm.12766

23. Trus M, Galdikiene N, Balciunas S, Green P, Helminen M, Suominen T. Connection between organizational culture and climate and empowerment: the perspective of nurse managers. Nurs Health Sci [Internet]. 2019 [cited 2019 Oct 09];21(1):54-62. Available from: https://www.ncbi.nlm. nih.gov/pubmed/30091283 


\section{NOTES}

\section{ORIGIN OF THE ARTICLE}

Extracted from the dissertation/thesis - Environment of the practice and empowerment of nurses in a hospital in Chile, presented to the Graduate Program in Nursing, Universidade Federal de Santa Catarina, in 2019.

\section{CONTRIBUTION OF AUTHORITY}

Study design: Masias KAA, Santos JLG.

Data collection: Masias KAA

Data analysis and interpretation: Masias KAA, Santos JLG.

Discussion of results: Masias KAA, Santos JLG.

Redaction and/or critical review of content: Masias KAA, Santos JLG, Erdmann AL

Review and approval of final version: Masias KAA, Santos JLG, Erdmann AL

\section{FIUNDING INFORMATION}

This study was financed in part by the Coordenação de Aperfeiçoamento de Pessoal de Nível Superior

- Brasil (CAPES) - Finance Code 001.

\section{APPROVAL OF ETHICS COMMITTEE IN RESEARCH}

Aproved by the Institutioanl Review Board at the Universidad de Magallanes.

\section{CONFLICT OF INTEREST}

There is no conflict of interest.

\section{HISTORICAL}

Received: November 01, 2019.

Approved: May 06, 2020.

\section{CORRESPONDING AUTHOR}

José Luís Guedes dos Santos

jose.santos@ufsc.br 